\title{
A Study on Proptech based Smart City and Smart Village Common Technology Demand
}

\author{
Jaehwan $\mathrm{Kim}^{1}$ and Yongkyung $\mathrm{Cho}^{2 *}$ \\ ${ }^{1}$ Associate Professor, Major in Real Estate Studies, Faculty of Regional Development, \\ Kongju Nat'l University. Yesan, Chungnam, Republic of Korea \\ ${ }^{2}$ Principal Researcher, Department of Research, Archi QPlus co., ltd., 233, 54, \\ Changeop-ro, Sujeong-gu, Seongnam-si, Gyeonggi-do, Republic of Korea

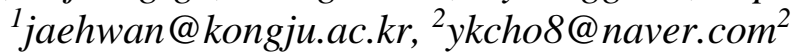

\begin{abstract}
Recently, proptech, which is a combination of property and technology, has been attracting attention, but it is necessary to apply proptech centered on urban spaces to areas centered on regions such as smart villages. Therefore, the purpose of this study was to derive common technology demands for smart cities for technology demand in urban areas and smart villages for rural technology demands based on the existing prop-tech concept for the real estate industry. As a method of research, we surveyed technology demand. To present a technology platform that can be reflected to prop technology from demand, it was set as a common technology demand range that encompasses this. This is because smart cities and smart villages are based on physical and technical environments in urban and non-urban areas, which means that the scope of the sharing economy and smart real estate technologies that reflect residential and convenient facilities are mutually reflected. Therefore, the common technology demand was divided into general and specialized types. The general type was categorized into cultural, welfare, and living environment services. The specialized type was divided into experience programs, visitor management, public relations, production distribution, accounting management, and facility management to derive detailed technical demands.
\end{abstract}

Keywords: Proptech smart city, Smart village, Common technology demand, Internet communication technology

\section{Introduction}

Proptech is a compound word of property and technology. At the end of 2010, the technology of combining ICT and real estate emerged around the United States and the United Kingdom, and virtual space was combined with real space to connect people. Intelligence has accelerated change [1]. Before the advent of Proptech, technological changes and social demands were changed from the concept of the ubiquitous city to smart city, and by this, the concept of smart city was changed and accommodated by changing the term smart village [2]. Ultimately, the demand for smart village technology in urban and rural smart cities was

Article history:

Received (June 6, 2020), Review Result (July 9, 2020), Accepted (August 11, 2020)

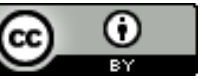

(c) 2020 Jaehwan Kim and Yongkyung Cho. Published by Global Vision Press

This is an open access article distributed under the terms of the Creative Commons Attribution License (CC BY4.0), which

permits unrestricted use, distribution, and reproduction in any medium, provided the original author and source are credited. 
derived from the ubiquitous city technology demand [3]. In addition, the recent demand for pro-tech combined with real estate is a situation in which technological change is accelerating as it is connected to mobiles in a more human- and object-friendly position with detailed technology demands of smart cities and smart villages [4]. In line with this, this study distinguishes common technology demand based on the concept of smart city for technology demand in urban areas and smart village concept for technology demand in rural areas based on existing prop-tech for space and real estate industries [5]. Through this, we would like to present a technology platform that can reflect the technological demands according to regional classifications in proptech. In addition, the scope of the research was limited to the common parts of smart cities and smart villages based on prop technology but was set as the range of common technology demands covering them [6]. This is because smart cities and smart villages are based on physical and technical environments in urban and non-urban areas, which means that the scope of the sharing economy and smart real estate technologies reflecting residential and convenience facilities are mutually reflected [Figure 1].

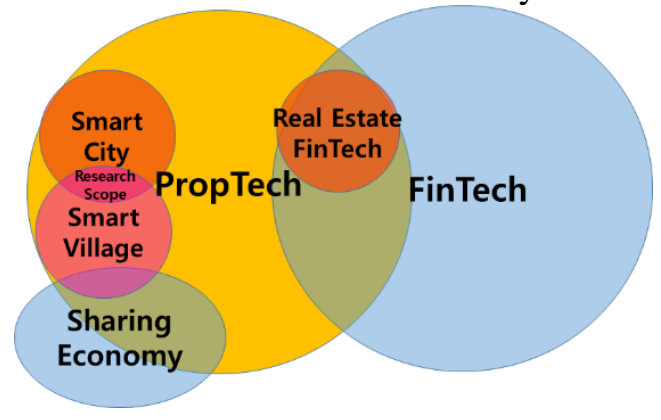

Figure 1. Scope of common technology demand applied in this study

\section{Theoretical considerations for smart cities and smart villages}

\subsection{Definition and characteristics of smart city}

Smart City is a concept developed from the existing U-City, innovating the existing information infrastructure for efficient urban functions and management, and grafting ubiquitous-based technology into the infrastructure to cope with all tasks occurring in the city in real-time and to communicate with information [6]. It is a city-based concept that provides services and provides convenient, safe, and comfortable living to residents [7]. This is because the intelligent city information system and IT service infrastructure that exist for citizens and residents can be freely connected to the network regardless of time and place, and each citizen and resident is not aware at all due to the information systems and service infrastructure built everywhere [8]. It refers to an environment in which the service can be naturally enjoyed even if it is not done. As an academic concept, by using Internet Communication Technology to provide it to urban spaces, we will increase the convenience of living, improve the quality of life, and innovate various functions such as systematic city management and energy saving, and create a wide variety of markets to create the nextgeneration new growth engine industry. It means a high-tech city that can play a role. Putting this together, it is a future city that combines Internet Communication Technology with space, providing citizens with the information they need anytime, anywhere, a smart city function that smartly manages the city, and a city space plan that makes people's lives more convenient (Urban Planning) refers to a city that combines concepts. The characteristics of a smart city are described in six aspects: eco-friendly city, ecological welfare network city, 
smart city, intelligent city, one-stop administrative service city, and others. The technical elements of smart cities are largely divided into infrastructure, data, and service, and are further divided into cities, ICT and spatial information infrastructure, IoT, data sharing, algorithms, and city services.

\subsection{Definition and characteristics of smart village}

The EU raised the necessity to develop an IT policy that bridges the information gap between rural areas and cities and digitally connects rural villages to achieve the vision of Cork Declaration 2.0 "Better Life in Rural Areas" as a background for smart village promotion. It also emphasized the need for a new approach to connect urban and rural areas, but to complement each other while maintaining their characteristics. In particular, the smart village strategy for the era of decentralization is focused on two things [9]. The first is the construction of smart villages as new cooperative governance in the era of decentralization. This means that to realize decentralization in the future, sustainable local development is important, such as revitalizing the local economy, creating local jobs, and increasing the level of local financial independence. Decentralization is only possible through aging, population reduction, poor infrastructure, vulnerabilities in local business environments, regional economic gaps, and local financial difficulties. The purpose of this project is to prepare for the era of decentralization as a smart village project that is expected to resolve the vulnerabilities in these regions and promote the development of the regional economy [10]. Second, Smart Village is to create new and innovative local business opportunities by discovering regional business demands and potentials. In particular, the Smart Village Project based on ICT is capable of revitalizing the local economy, innovating local services, improving product production processes, and efficiently utilizing local resources. In addition, it intends to establish a new regional network foundation and build a digital village ecosystem through a digital platform that intelligently connects local governments.

Based on the definition of the EU earlier, in Korea, ICT-based tangible programs ( $\mathrm{H} / \mathrm{W}+$ $\mathrm{S} / \mathrm{W}$ ) were introduced in rural development, creating synergies through cooperation between ministries and related projects, creating agricultural competitiveness and farm income., ICT Creation Village is underway to dramatically improve the conditions of settlement such as education, medical care, and culture. This project is a new rural business model based on the spirit of independence (income), voluntary (cooperative), and self-help (shared economy). It is a content-type village that combines ICT-based agricultural production, distribution, education, culture, and welfare. Here, the technical demands of Smart Village are organized as follows.

\section{Derivation and application of common technology demand}

\subsection{Common technology demand survey}

Community classification for the common technology demand survey that can cover both smart cities and smart villages was based on the following types. First, it focuses on the urban-oriented point of view rather than the existing urban type aspect and is classified into five types according to the core resources and development factors of urban villages. First, in terms of economic orientation, 'agricultural type' focusing on agricultural production, 'distribution processing type' that promotes added value through the distribution and processing of agricultural and marine products, and 'provincial and rural areas that use urban resources to attract urban residents and increase non-farm income. From an exchange- 
oriented aspect to a 'life-based type' through the improvement of basic conditions such as public services to improve the living environment of residents in an infrastructure-oriented aspect, and a 'life-satisfaction type' seeking a quality of life through community activities in a value-oriented aspect was divided [11]. In line with this, the community type for the common technology demand survey is to improve self-governing activity type that seeks value and pursues quality of life, urban and rural exchange type that pursues economic orientation and income increase, income production type, infrastructure orientation, and basic living conditions. It was categorized as a life-based type for the purpose [12]. In particular, in the service demand survey, the basic information of the community was grasped, and the current status of the community engaged in urban and rural exchange activities, income and production activities, and autonomous activities and future technical demand were conducted [13].

\subsection{Common technology demand survey}

From November 1, 2019, to November 15, 2019, 500 households were selected through convenience allocation by region for municipalities in Korea, and a complete survey was conducted. Before the common technology demand survey, the status diagnosis items include respondent characteristics (gender, name, age, address, residence period, education, occupation, job title) and life service indicators (road, water and sewage, welfare, residential environment, education, economic and community organization, Social service).

Table 3. Basic information on service demand survey

\begin{tabular}{|c|c|c|c|c|c|c|c|c|c|c|}
\hline Div. & Total & Experience & Visitor & Promotion & $\begin{array}{c}\text { Production } \\
\text { distribution }\end{array}$ & $\begin{array}{c}\text { Accounti } \\
\text { ng }\end{array}$ & $\begin{array}{c}\text { Autonomous } \\
\text { activities }\end{array}$ & Culture & Welfare & $\begin{array}{c}\text { Life } \\
\text { Environment }\end{array}$ \\
\hline Frequency & 500 & 57 & 55 & 61 & 45 & 47 & 55 & 78 & 67 & 35 \\
\hline Percentage & 100 & $11.4 \%$ & $11.0 \%$ & $12.2 \%$ & $9.0 \%$ & $9.4 \%$ & $11.0 \%$ & $15.6 \%$ & $13.4 \%$ & $7.0 \%$ \\
\hline
\end{tabular}

Respondents said that the average age of all respondents was in their 60s, and elderly people in their 60 s or older accounted for $82 \%$ of all respondents, and among the major activities in the community, urban and rural exchange activities accounted for $78 \%$ of the total. It was found that the technological convergence between smart villages and the demand for common element technologies are important. In addition, it was found that $92 \%$ of the total is viewing the business through a smartphone, and mutual communication is also conducted through SNS. The service required for the experience field, which is identified as a key item among the demands of smart village technology, has a high need for specialized areas such as content discovery and program operation.

Table 4. Common technology demand analysis results

\begin{tabular}{|c|c|c|}
\hline Div. & Technical service area & Detailed technology \\
\hline \multirow{2}{*}{$\begin{array}{c}\text { General } \\
\text { type }\end{array}$} & Cultural services & $\begin{array}{c}\text { Idle spatial information provision system, program information } \\
\text { provision and application management service, idle mentor } \\
\text { information provision system, related equipment information provision } \\
\text { system }\end{array}$ \\
\cline { 2 - 3 } & Welfare services & $\begin{array}{c}\text { - Health self-diagnosis service technology, medical facility location } \\
\text { information service technology, emergency information service } \\
\text { technology }\end{array}$ \\
\hline
\end{tabular}




\begin{tabular}{|c|c|c|}
\hline & $\begin{array}{l}\text { Life Environment } \\
\text { services }\end{array}$ & $\begin{array}{l}\text {-Road and water service information service technology, public } \\
\text { transportation location information service technology, water quality } \\
\text { check system technology, water rate information system technology, } \\
\text { road and water service information service technology, elementary and } \\
\text { middle and high school education support service technology, remote } \\
\text { social services (financial and Public agency work), social services to } \\
\text { visit (financial and public agency work) }\end{array}$ \\
\hline \multirow{6}{*}{$\begin{array}{l}\text { Specialized } \\
\text { type }\end{array}$} & $\begin{array}{l}\text { Experience program } \\
\text { service }\end{array}$ & $\begin{array}{c}\text { - Content discovery technology, program consulting technology, } \\
\text { teaching plan creation and tool development technology, program } \\
\text { souvenir production technology }\end{array}$ \\
\hline & $\begin{array}{l}\text { Visitor management } \\
\text { service }\end{array}$ & $\begin{array}{l}\text { - Visit reservation technology, visit counting system, visit } \\
\text { management, integrated management system }\end{array}$ \\
\hline & $\begin{array}{l}\text { Public Relationship } \\
\text { service }\end{array}$ & $\begin{array}{l}\text { - PR method presentation technology, PR support information service } \\
\text { technology }\end{array}$ \\
\hline & $\begin{array}{l}\text { Production and } \\
\text { distribution service }\end{array}$ & $\begin{array}{l}\text { - Production and environmental control technology. Storage } \\
\text { technology, distribution technology }\end{array}$ \\
\hline & $\begin{array}{c}\text { Accounting } \\
\text { Management Service }\end{array}$ & $\begin{array}{l}\text { Accounting program, payment agency service technology, automatic } \\
\text { payment accounting general information system technology, } \\
\text { fingerprint reader for commuting }\end{array}$ \\
\hline & $\begin{array}{l}\text { Facility management } \\
\text { service }\end{array}$ & $\begin{array}{l}\text { - Air-conditioning control system, anti-theft system, video conference, } \\
\text { electronic voting, mobile residents participation system }\end{array}$ \\
\hline
\end{tabular}

The above analysis results of common technology demand are divided into the general type and specialized type according to the technical service area. In Smart City and Smart Village, general culture, welfare, and living environment services are performed in both regions, and the specialized type is considered to be the case when the functions of the city and the countryside overlap. It is expected that the experience program, visitor management, public relations, production distribution, accounting management, and facility management can be variably used according to the situation. As a result, it was possible to grasp the detailed technology as the technical demand that should ultimately be included in the two regions.

\section{Conclusion}

Based on the prop-tech technology base, this study summarizes the demand for service technologies that are commonly included in smart cities in urban areas and smart villages in non-urban areas through research methods. This is derived from the ubiquitous city technology demand in the smart town and rural areas of smart town. In line with this, Protech's existing demand combined with the product unit called real estate is accelerating technological change by connecting with mobiles in a human- and object-friendly position along with detailed technology demands of smart cities and smart villages. In line with this periodic situation, this study began by analyzing the common technology demands covering smart cities and smart villages, and in the future, organizing the demands for the sources of ICT technology demands necessary for the regional land management policy according to regional classification. Through this, in this study, the common technology demands were divided into general and specialized types as follows. The general type selects detailed technologies for each service type by culture, welfare, and living environment services. The specialized type specializes in the production, processing, and experiences for cities and rural areas through experience, visitor management, public relations, accounting management, and 
facility management services. The detailed technology composed was prepared. Through this, the city and rural policies should be pre-planned by the demands of each detailed technology, and efficient distribution of resources and improvement of equity should be considered through post-development.

\section{References}

[1] J. Kyung and D. Kwan, "A study on the influencing factors of real estate industry's acceptance of information technology in the 4th industrial revolution," Korea Real Estate Association, vol.36, no.3, pp.183-198, (2018)

[2] E. Hong, "A study on the planning of aging-friendly remodeling of public apartment: focused on lh apartment in Incheon," Incheon University, (2018)

[3] Y. Hyun, "Creative economy village and the future sixth industry," STSS Sustainable Science Society, pp.72$75,(2016)$

[4] Y. Cho et al., "LH smart city future vision and promotion strategy," Korea Land \& Housing Corporation, Land Housing Research Institute, (2018)

[5] J. Ha, "The Era of Proptech approach is approaching," Korean Society of Civil Engineers, vol.67, no.7, (2019)

[6] Korea Research Institute for Human Settlements, 4th Industrial Revolution and Change in Real Estate Market, Monthly Land Information, (2019)

[7] Korea Ubiquitous City Association, U-City Status and Activation Plan, (2010)

[8] National Assembly Legislative Survey, Smart City Status and Development Direction, (2016)

[9] A. Baum, PropTech 3.0: the future of real estate, University of Oxford Research, (2017)

[10] European Commission, EU Action for SMART VILLAGES, (2017)

[11] Korea Informatization Promotion Agency, "ICT project to activate the European regional economy," Smart Village, EU Action for SMART VILLAGE by EC, (2018)

[12] Chai S.-S. and Suh D., "Design of risk analysis database system based on open data for South Korea," J. Stat. Comput. Algorithm, vol.2, pp.1-6, (2018)

[13] European Network for Rural Development, German strategies for Digitising Rural Areas, (2018)

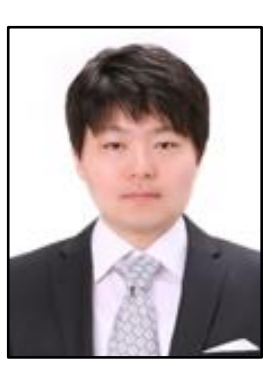

\section{Authors}

\section{Dr. Jaehwan, Kim}

$\mathrm{He}$ is an assistant professor at the Department of Regional development, Kongju Nat'1 University, South Korea.

His research interests are mixed use development, feasibility study, and decision making methodology.

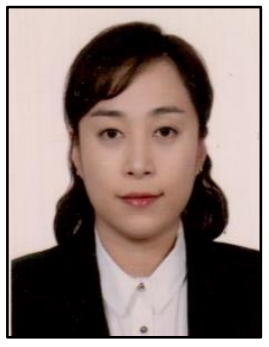

\section{Dr. Yongkyung, Cho}

She is a principal researcher at Korea Housing and Urban Research Institute of Archi Q Plus Co., Ltd. in South Korea.

Her research interests are fusion and convergence development, feasibility study and probtech like Smart Housing and public policy. 